\title{
Assessment of sustainability in Austrian wine production
}

\author{
Franz Gerhard Rosner ${ }^{1}$, Wolfgang Dobritzhofer ${ }^{4}$, Alois Geyrhofer ${ }^{1}$, Josef Glatt ${ }^{3}$, Stefan Großauer ${ }^{2}$, Siegfried Pöchtrager ${ }^{2}$, \\ Ferdinand Regner ${ }^{1}$, Norbert Sauberer ${ }^{5}$, Harald Scheiblhofer ${ }^{1}$, Gregor Sellner ${ }^{6}$, Gerhard Soja ${ }^{7}$, Karl Vogl ${ }^{1}$, and Franz Zehetner ${ }^{2}$ \\ ${ }^{1}$ Höhere Bundeslehranstalt und Bundesamt für Wein- und Obstbau, A-3400 Klosterneuburg, Wiener Straße 74, Austria \\ ${ }^{2}$ Universität für Bodenkultur, A-1180 Wien, Gregor-Mendel-Straße 33, Austria \\ ${ }^{3}$ Österreichischer Weinbauverband, A-1014 Wien, Schauflergasse 6, Austria \\ ${ }^{4}$ Landwirtschaftskammer Niederösterreich, A-3100 St. Pölten, Wiener Straße 64, Austria \\ ${ }^{5}$ Institut für Naturforschung und Ökologie GmbH, A-1090 Wien, Giessergasse 6/7, Austria \\ ${ }^{6}$ SERI Nachhaltigkeitsforschungs- und -kommunikations GmbH, A-1090 Wien, Garnisongasse 7/17, Austria \\ ${ }^{7}$ AIT Austrian Institute of Technology GmbH, A-3430 Tulln, Konrad-Lorenz-Straße 24, Austria
}

\begin{abstract}
The aim of the project was to find out whether environmental sustainability can be measured not only with regard to climate change and carbon consumption but also as to other criteria concerning material consumption, energy, soil, biodiversity and water. We investigated which measures in the vineyard and wine cellar can lead to "better" sustainability while ensuring a high quality standard. 343 activities were identified to fulfill 61 quality objectives. Of the 2,191 sustainability assessments that were determined the measurements of the individual sustainability criteria vary and are in some cases even negatively correlated. Nevertheless, it was still possible to differentiate sustainably managed wineries from others in all of the Austrian wine producing areas. In our approach, a specifically developed online tool can calculate the expression of ecological, economic and social sustainability and show the effects in a spider diagram in the form of a traffic light rating system. Moreover, an algorithm suggests adequately which quality improvements can be achieved. If part of the management system is changed the online tool will show the positive and negative sustainability effects.
\end{abstract}

\section{Introduction}

In 1987, the "Report of the World Commission on Environment and Development: Our Common Future" (Brundtland-Report) defined sustainability for the first time as "... development that meets the needs of the present without compromising the ability of future generations to meet their own needs" [2]. It should be pointed out in this context that sustainability and corporate social responsibility are used as equivalent terms: "An increasing number of European companies are promoting their corporate social responsibility (CSR) strategies as a response to a variety of social, environmental and economic pressures" [3]. Sustainable and responsible businesses "should have in place a process to integrate social, environmental, ethical human rights and consumer concerns into their business operations and core strategy in close collaboration with their stakeholders" [3]. A strategic approach to CSR is becoming increasingly important for the competitiveness of enterprises. "Many of the factors affecting the business case of CSR are themselves dynamic and are intensifying, such as employee expectations, consumer awareness, trends in private and public procurement" [...and...] "the nature of innovation processes..." [4].

Grape vines are demanding plants which produce physiologically ripe grapes only in certain regions. Hence wine production has been developed and established in those suitable areas for many centuries. This and the fact that grapevines are cultivated in permanent culture means that unqualified activities in the vineyard lead to long-term problems, e.g. soil compaction, water pollution or destruction of fauna and flora. This environmental degradation can endanger the continued existence of viticulture.

Sustainable vitiviniculture is defined by the International Organisation of Vine and Wine (OIV) as a "global strategy on the scale of the grape production and processing systems, incorporating at the same time the economic sustainability of structures and territories, producing quality products, considering requirements of precision in sustainable viticulture, risks to the environment, product safety and consumer health and valuing of heritage, historical, cultural, ecological and landscape aspects. Activities in the vine and wine sector are highly dependent on natural resources: solar energy, climate, water, soils and the successful integration of these elements with ecological processes" [12]. Further recommendations are in progress by the OIV.

Not only expert communities, but also consumers have become much more environmentally conscious. The production of integrated and organic wine has therefore increased. Following consumer demand, Austrian organic viticulture accounts for 4.259 ha or $10 \%$ of the total cultivated vineyard surface, thereby taking first place in Europe (Germany $5.2 \%$, Italy $6.8 \%$, France $6 \%$ and Spain $5 \%$, world production $2 \%$ ) [1]. 
Numerous organic organizations have independently from each other developed additional criteria for plant protection and fertilization over the years. An example for such a mandatory specification defines that "... compost preparations consist of herbs..., most of which are filled into particular animal origins, hung in the summer sun or placed in the soil for some months where they collect cosmic forces during this time" [8]. The Anglo-American countries in particular have taken on a leading role in all aspects of sustainability, including the main processes of the production chain. In 2003, the California Sustainable Winegrowing Alliance was incorporated "... to ensure that the California wine community is recognized as a change leader in the global marketplace."..."The result of this work will be a healthier environment, stronger communities and vibrant business." [6].

The kind of measures and the categorizations used in existing certification systems did not comply with the principle of proportionality, the Austrian wine standards and growing conditions, and the measurements used were incomplete. For example, "The Lodi Rules for Sustainable Winegrowing Farming Practices Standards" awards points for monitoring the vineyard for insect, mite and pests at least once every 10 days (6 points), 14 days (4 points) 21 days ( 2 points) and a month (0 points) [10]. Another example categorizes one criterion into several qualitative intensities on soil compaction, activities are explained in category 1 as "I do not consider soil compaction when choosing equipment and equipment is driven in the vineyard regardless of soil moisture (including when there is the possibility of getting stuck)" and category 4 describes "I choose or modify equipment to minimize soil compaction (e.g., operate lightest equipment possible use tracklayers, install wide or greater diameter tires, reduce tire pressure as much as possible) and equipment never enters the vineyard during wet soil conditions and a permanent or non-tilled and reseeded annual cover crop is maintained" [7]. However, soil compaction affects not only soil, it influences among other things water-holding capacity, biodiversity, longevity of vines and grape quality. In addition, this kind of a categorisation shows only quality and not quantity.

Different precipitation regimes and other environmental criteria mean that different regions use certain technologies more or less frequently, and/or use different technologies altogether. Basically intensified management results in more resources being consumed and this adversely affects sustainability. However, in environmentally friendly organic farming - even though fewer toxic substances are applied machines are used more frequently and thus consume more resources. On the other hand, reduced resource input can potentially lead to improper and sloppy management, which in turn can cause a loss of quality and endanger the vineyard.

The aim of this study was to create a sustainability measurement tool, which would take the regional differences and different management systems in the Austrian wine sector into account. It should also consider the quality of environmental sustainability, which should not only merely be measured in terms of carbon consumption, but also by other criteria such as energy consumption, material consumption, soil, biodiversity and water. The entire production chain, from the vineyard to the labelled and packaged bottles (cradle to factory gate), as well as social and economic criteria is incorporated.

\section{Materials and methods}

The project is based on the experience from WEINKLIM [14] and inventories of the international sustainability certification drawn up in two B.A. project papers written at the University of Natural Resources and Life Sciences, Vienna [13,11].

These findings were evaluated together with vintners, stakeholders and national sustainability experts (SE) at a workshop in 2011.

\subsection{Ecological sustainability}

To begin with, data was collected over a 12-month period regarding all aspects of the vintner's tasks. In order to encompass the entire production chain of winemaking, the three processes grape growing, wine production and vineyard planting were considered in the study. The data collected within these processes was from tasks which would help achieve defined quality objectives. All activities suitable for measuring sustainability have been included (Tables 1a-c). Seven areas (Fig. 1) have been defined as sustainability criteria (SC). All activities along the production chain were evaluated by experts (SE) in each SC (Tables 1a-c).

Each assessment was scientifically defined within a scale ranging from -10 to +10 with zero meaning insignificant or having a neutral effect. In tandem interviews two SE presented their results to wine experts and scientists of the Federal Education and Research Institute for Viticulture and Pomology in Klosterneuburg and the University of Natural Resources and Life Sciences in Vienna. These interviews were recorded and new findings incorporated into the study. This allowed activities to be defined more precisely. What is more, the SE came up with further implementations to improve sustainability in the wine sector. Consequently a second round of interviews had to be carried out.

The various tasks in the process of vineyard planting can affect grape production to greater or lesser extent. For

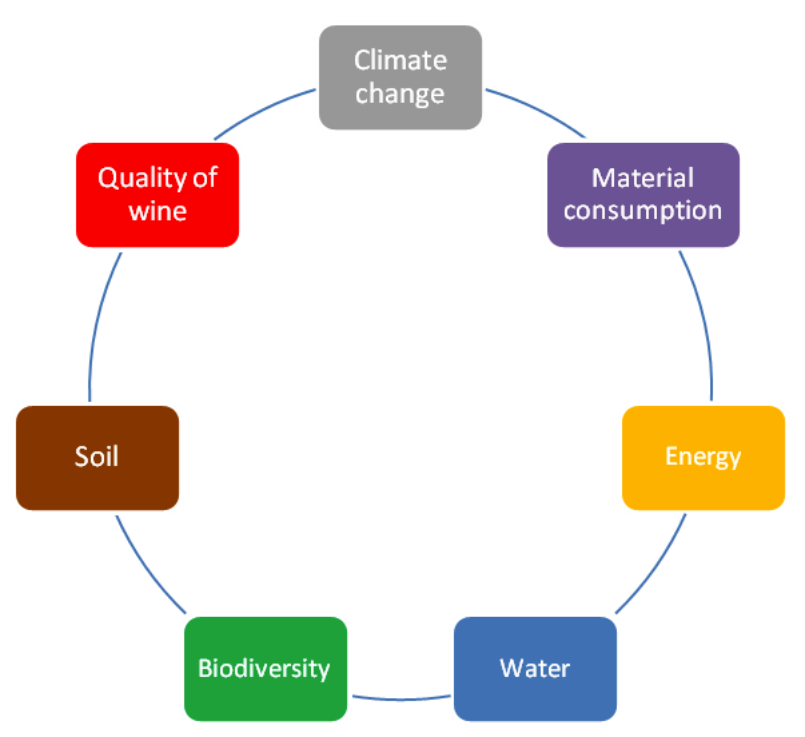

Figure 1. Sustainability criteria. 
Table 1a. Overview of quality aims, activities and sustainability assessments (grape production).

\begin{tabular}{|c|c|c|c|c|}
\hline \multirow[t]{20}{*}{ Grape production } & Quality criteria & $\begin{array}{l}\text { Range of activities to } \\
\text { fulfill quality criteria }\end{array}$ & $\begin{array}{c}\text { Sustainability criteria } \\
\text { per activity }\end{array}$ & $\begin{array}{l}\text { Number of assessments } \\
\text { carried out for each } \\
\text { quality criterion }\end{array}$ \\
\hline & Machinery use & 3 & 7 & 21 \\
\hline & Fuel use & 3 & 7 & 21 \\
\hline & $\begin{array}{l}\text { Technical application } \\
\text { measures }\end{array}$ & 9 & 7 & 63 \\
\hline & Canopy management & 4 & 7 & 28 \\
\hline & $\begin{array}{l}\text { Diseases caused by fungal } \\
\text { pathogens }\end{array}$ & 9 & 7 & 63 \\
\hline & $\begin{array}{l}\text { Pests caused by animal } \\
\text { pathogens (insecticides) }\end{array}$ & 9 & 7 & 63 \\
\hline & $\begin{array}{l}\text { Other kinds of plant } \\
\text { protection, e.g. false-trail- } \\
\text { following techniques }\end{array}$ & 3 & 7 & 21 \\
\hline & Crop protection & 8 & 7 & 56 \\
\hline & $\begin{array}{l}\text { Landscape features and } \\
\text { biodiversity measures }\end{array}$ & 6 & 7 & 42 \\
\hline & Green covering & 5 & 7 & 35 \\
\hline & Fertilization & 9 & 7 & 63 \\
\hline & Soil management & 10 & 7 & 70 \\
\hline & Irrigation & 3 & 7 & 21 \\
\hline & Water management & 4 & 7 & 28 \\
\hline & Pruning & 3 & 7 & 21 \\
\hline & Vine stem management & 3 & 7 & 21 \\
\hline & Leaf canopy height & 3 & 7 & 21 \\
\hline & $\begin{array}{l}\text { Cluster management, e.g. } \\
\text { thinning out superfluous } \\
\text { grapes }\end{array}$ & 5 & 7 & 35 \\
\hline & Selective harvest & 3 & 7 & 21 \\
\hline Total & 19 & 102 & Each 7 & 714 \\
\hline
\end{tabular}

example, preliminary fertilization during vineyard planting is a treatment to ensure nutrient supply for the entire life cycle of the vineyard. On the other hand, inorganic fertilization in the process of grape production is hardly ever necessary. This shows that there are varying degrees of relevance in SC.

As a consequence each SE defined the relative significance of the three processes grape production, wine production and vineyard planting to each other. In the next step vitiviniculture consultants selected 31 vintners and wineries, among which were large and small, organic and conventional as well as pioneering and traditional companies to test practical applicability. The effective operational data of these 31 vintners and wineries was reevaluated by SE. For this final survey the project team developed an online tool to enable rapid data collection and automatic data evaluation. This data included $\mathrm{min} / \mathrm{max}$-values, average and $0.25,0.5$ and 0.75 quartiles per process, quality target and activity.

\subsection{Social and economic sustainability}

Quality objectives for the social and economic process as well as relevant activities were defined. In analogy to the process used for ecological sustainability the same evaluation procedure was carried out (Tables 1d-e).

In total 343 activities with 2,191 sustainability assessments were determined to achieve 61 quality objectives.

\subsection{Definition of sustainability limits}

Allowing for the different types of the Austrian landscape's growing conditions, such as slopes (southern Styria) and flat terrain (Lake Neusiedlersee), or regional differences in annual precipitation into account, nine vitiviniculture consultants from every Austrian wine region entered data regarding all activities into the online tool, defining these activities as "green" (sustainable) or "red" (unsustainable) (see Appendix 1). 
Table 1b. Overview of quality aims, activities and sustainability assessments (wine production).

\begin{tabular}{|c|c|c|c|c|}
\hline \multirow[t]{17}{*}{ Wine production } & Quality criteria & $\begin{array}{c}\text { Range of } \\
\text { activities } \\
\text { to fulfill } \\
\text { quality } \\
\text { criteria }\end{array}$ & $\begin{array}{l}\text { Sustainability } \\
\text { criteria per } \\
\text { activity }\end{array}$ & $\begin{array}{c}\text { Number of } \\
\text { assessments carried } \\
\text { out for each quality } \\
\text { criterion }\end{array}$ \\
\hline & Building isolation and energy-saving activities & 9 & 7 & 63 \\
\hline & Resource efficiency & 2 & 7 & 14 \\
\hline & Energy sources & 11 & 7 & 77 \\
\hline & Temperature control of mash & 7 & 7 & 49 \\
\hline & Fermentation control & 7 & 7 & 49 \\
\hline & Alcohol enrichment operations & 7 & 7 & 49 \\
\hline & Wine making techniques & 19 & 7 & 133 \\
\hline & Storage conditions & 4 & 7 & 28 \\
\hline & Bottle cleaning and filling & 7 & 7 & 49 \\
\hline & Type of bottle & 9 & 7 & 63 \\
\hline & Type of corking & 6 & 7 & 42 \\
\hline & Type of packaging & 4 & 7 & 28 \\
\hline & Cleaning methods & 5 & 7 & 35 \\
\hline & Waste water treatment & 5 & 7 & 35 \\
\hline & Waste management & 8 & 7 & 56 \\
\hline & Recordings & 4 & 7 & 28 \\
\hline Total & 16 & 114 & Each 7 & 798 \\
\hline
\end{tabular}

Table 1c. Overview of quality aims, activities and sustainability assessments (vineyard planting).

\begin{tabular}{|c|c|c|c|c|}
\hline \multirow[t]{16}{*}{$\begin{array}{l}\text { Vineyard } \\
\text { planting }\end{array}$} & Quality criteria & $\begin{array}{l}\text { Range of activities to } \\
\text { fulfill quality criteria }\end{array}$ & $\begin{array}{c}\text { Sustainability criteria } \\
\text { per activity }\end{array}$ & $\begin{array}{l}\text { Number of assessments } \\
\text { carried out for each } \\
\text { quality criterion }\end{array}$ \\
\hline & Location of vineyard & 5 & 7 & 35 \\
\hline & Soil type & 5 & 7 & 35 \\
\hline & Erosion prevention & 13 & 7 & 91 \\
\hline & Planting material & 5 & 7 & 35 \\
\hline & Choice of variety and rootstock & 6 & 7 & 42 \\
\hline & Training system & 6 & 7 & 42 \\
\hline & Kind of pole & 8 & 7 & 56 \\
\hline & Machinery use & 5 & 7 & 35 \\
\hline & Preparation of the soil & 3 & 7 & 21 \\
\hline & Fertilization & 8 & 7 & 56 \\
\hline & Green covering & 6 & 7 & 42 \\
\hline & Site-specific planting & 3 & 7 & 21 \\
\hline & Irrigation & 4 & 7 & 28 \\
\hline & Weed control & 9 & 7 & 63 \\
\hline & $\begin{array}{l}\text { Landscape features and biodiversity } \\
\text { measures }\end{array}$ & 6 & 7 & 42 \\
\hline Total & 15 & 92 & Each 7 & 644 \\
\hline
\end{tabular}


Table 1d. Overview of quality aims, activities and sustainability assessments (social affairs).

\begin{tabular}{|c|c|c|c|c|}
\hline \multirow[t]{9}{*}{ Social Affairs } & Quality criteria & $\begin{array}{l}\text { Range of activities to } \\
\text { fulfill quality criteria }\end{array}$ & $\begin{array}{c}\text { Sustainability } \\
\text { criteria per activity }\end{array}$ & $\begin{array}{c}\text { Number of } \\
\text { assessments carried } \\
\text { out for each quality } \\
\text { criterion }\end{array}$ \\
\hline & Protection of employees & 2 & 1 & 2 \\
\hline & Fair pay and gender equality & 4 & 1 & 4 \\
\hline & Social security benefits & 2 & 1 & 2 \\
\hline & Choice of external service providers & 2 & 1 & 2 \\
\hline & $\begin{array}{l}\text { Providing educational programs and } \\
\text { professional training }\end{array}$ & 2 & 1 & 2 \\
\hline & $\begin{array}{l}\text { Promoting a positive working } \\
\text { atmosphere }\end{array}$ & 3 & 1 & 3 \\
\hline & Recruitment of disabled workers & 1 & 1 & 1 \\
\hline & Safety at work & 9 & 1 & 9 \\
\hline Total & 8 & 25 & Each 1 & 25 \\
\hline
\end{tabular}

Table 1e. Overview of quality aims, activities and sustainability assessments (economy).

\begin{tabular}{|l|l|c|c|c|}
\hline \multirow{4}{*}{ Economy } & \multicolumn{1}{|c|}{ Quality criteria } & $\begin{array}{c}\text { Range of activities to } \\
\text { fulfill quality criteria }\end{array}$ & $\begin{array}{c}\text { Sustainability criteria } \\
\text { per activity }\end{array}$ & $\begin{array}{c}\text { Number of assessments } \\
\text { carried out for each } \\
\text { quality criterion }\end{array}$ \\
\cline { 2 - 5 } & $\begin{array}{l}\text { Sustainable business } \\
\text { management }\end{array}$ & 5 & 1 & 5 \\
\cline { 2 - 5 } & $\begin{array}{l}\text { Promoting regional } \\
\text { activities }\end{array}$ & 3 & 1 & 3 \\
\cline { 2 - 5 } & Economic importance & 2 & 1 & 2 \\
\hline Total & $\mathbf{3}$ & $\mathbf{1 0}$ & Each $\mathbf{1}$ & $\mathbf{1 0}$ \\
\hline
\end{tabular}

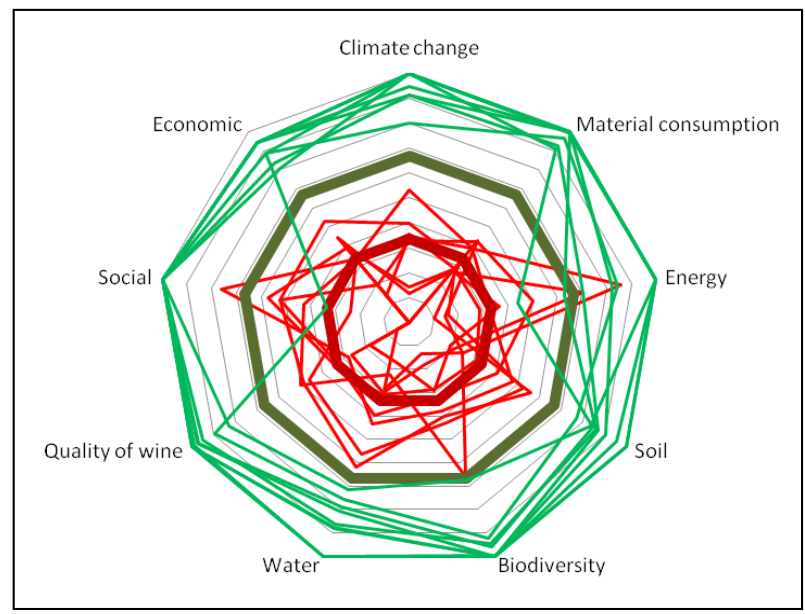

Figure 2. Unsustainably producing wineries (center to thick red line) and sustainably producing wineries (thick green line to edge of diagram).

Figure 2 shows nine "green" and nine "red" datapoints from the consultants and their sustainability characteristics in the various sustainability categories. In one instance, a "green" winery borders on the red zone concerning social criterion and vice versa a "red" winery operates in the "green" sustainable energy area. This proves that sustainably and unsustainably producing wineries can be defined by this system.

\section{Results and discussion}

In accordance to the nine "green" and nine "red" model winery data of the vitiviniculture consultants the red border zone was determined by 0.25 quartile of all 18 wineries, the yellow border zone by 0.5 quartile of the nine "green" wineries and the green zone above. In other words $50 \%$ of the "red" and $50 \%$ of the "green" wineries are located in the yellow zone in order to guarantee that only sustainably producing wineries of all Austrian wine regions attain the green area. However, some indicators show annual variances as for example new vineyards are only planted when necessary. The proceeding to rectify data from different kinds of wineries is the introduction to determine the distance of the yellow zone as 1 . This interval is exactly the same for the red and green zones. Consequently, a sustainable winery in the process grape production has a value of between 2 and 3. Therefore a winery has a value of 2.3 in grape production (e.g. $40 \%$ sustainability severity of the whole production in this SC) and 2.5 in wine production (e.g. $40 \%$ sustainability severity of the whole production in this SC) the final value in the spider diagram results in 2.4. 
Wineries with one or more sustainability criteria in the "red" area should not be classified as sustainable. If a winery meets all the above-mentioned sustainability criteria, it is issued a sustainability certificate by an authorised company. During a transitional phase scores between the red and green thick lines may be tolerated until sufficient operational data is available whereupon the system will ask for a readjustment.

A user-friendly online tool can help to ensure that wineries use this certification in order to promote their sustainable management to consumers (Fig. 3). Downloads of checklists and for documentations of activities ensure an efficient certification process.

The online system provides an overview of how sustainable each activity is. This can lead to positive steering effects within the wineries (Figs. 4 and 5). What is more, the wineries respond to the general consumer demand of "green" products and taking responsibility for future generations.

An annual data evaluation and system improvement/update can be achieved by introducing new and

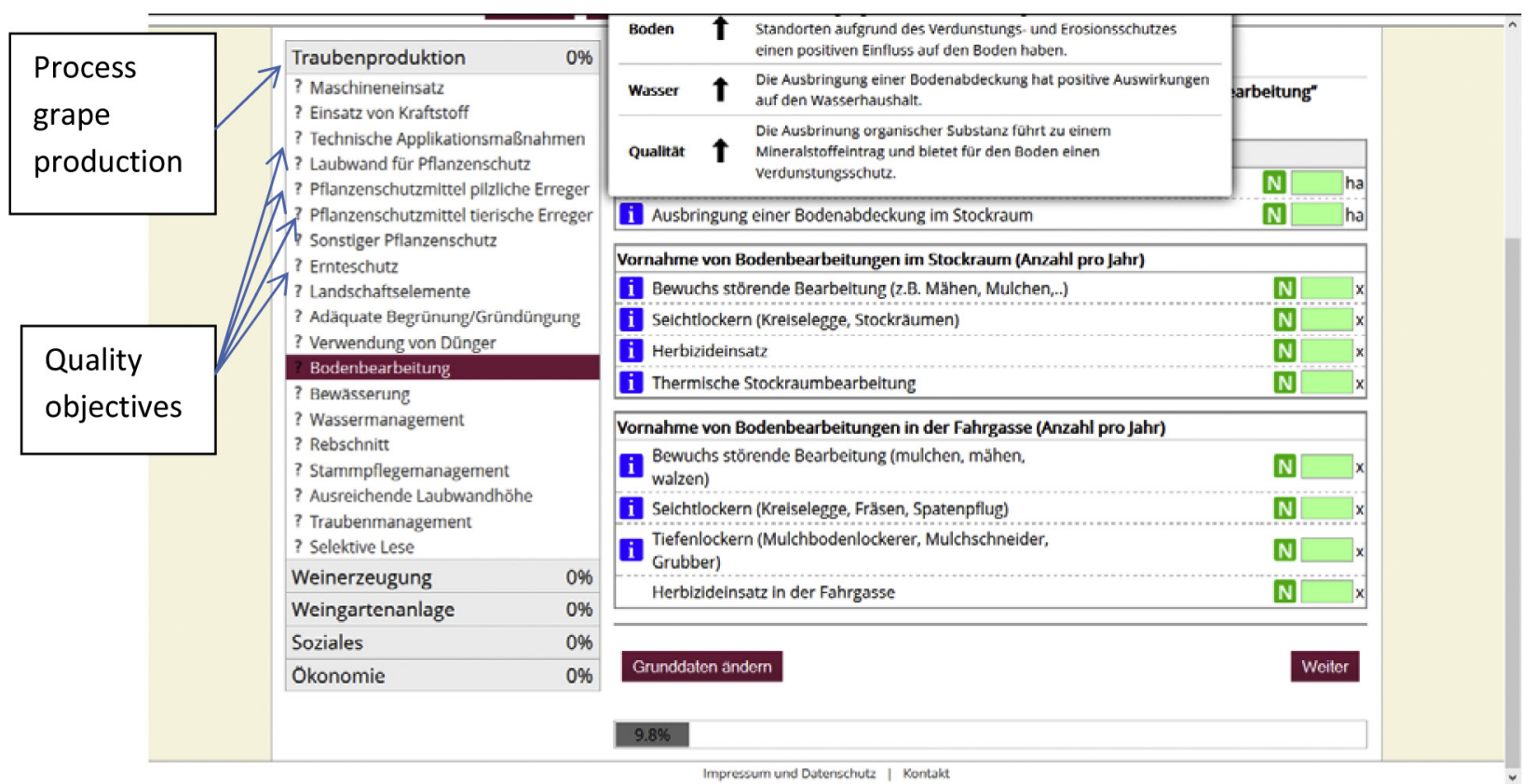

Figure 3. Sustainability overview click: a click on button "N" shows more or less effect (arrow) of an activity, explanations in each sustainability criterion.

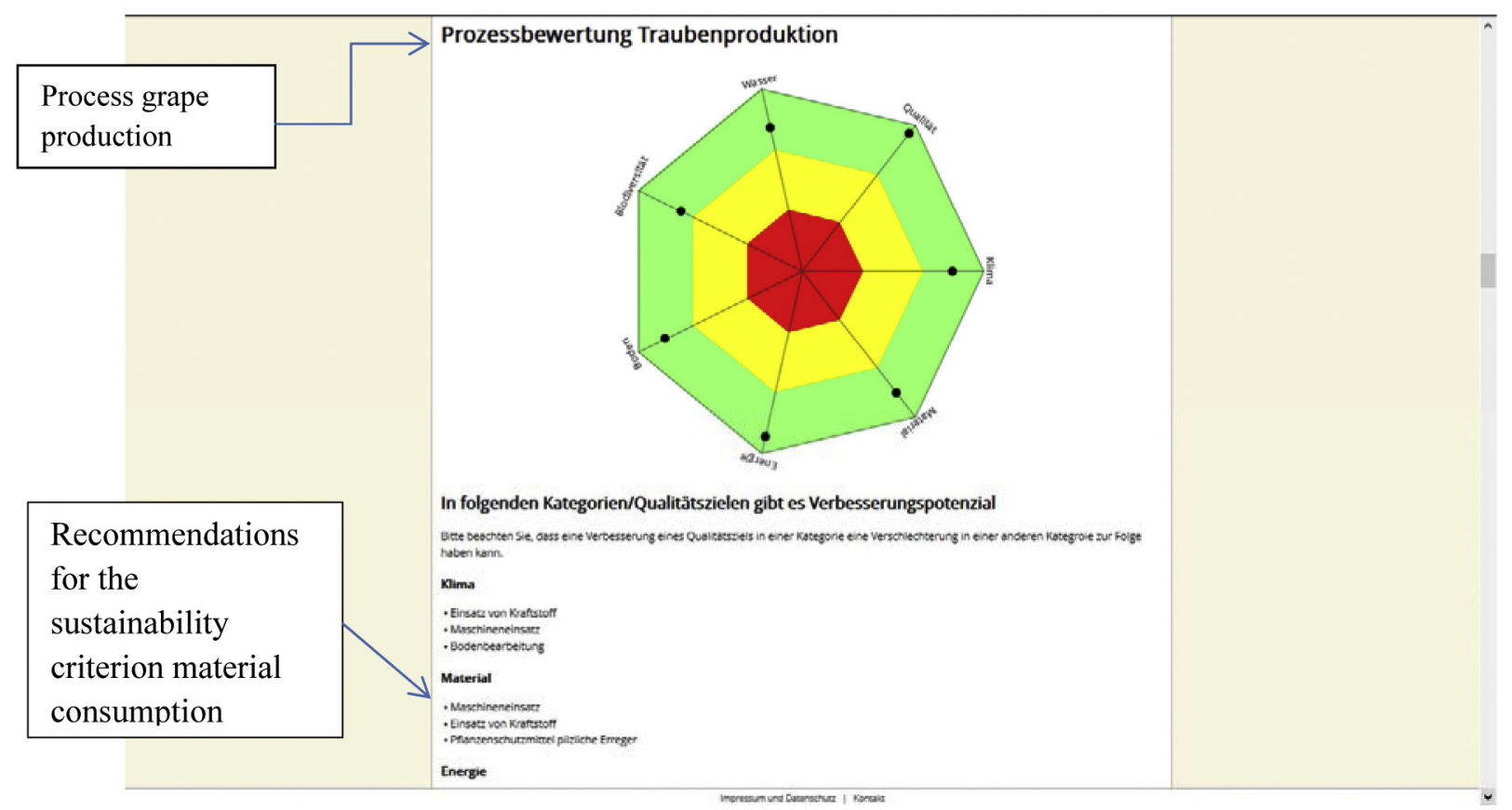

Figure 4. Three recommendations for each sustainability criterion per process. 
Gesamtbewertung (2013)

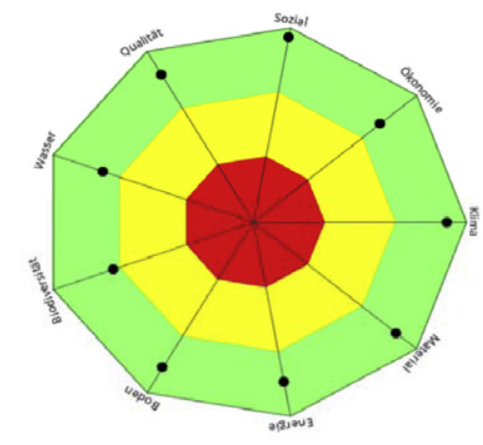

Figure 5. Final evaluation of a sustainably producing winery.

supplementary activities and adapting the assessment of activities according to the latest scientific evidence.

\section{Appendix 1}

"Green" vitiviniculture

- Vineyard planting: A vintner who plants the vineyard in such a way that long-term sustainable management is possible.

- Grape production: A vintner that operates in accordance with ecological/sustainable principles to produce high quality grapes (organic or better integrated production).

- Wine production: A winery which operates so as to use resources efficiently and avoid errors, for producing and packaging quality wine on a high level.

- Social: A winery which fulfills the high legal standards for workers' rights and safety, and which takes its social responsibility seriously.

- Economy: A winery which operates economically in the long run according to the company data and the resources used.

"Red" vitiviniculture

- Vineyard planting: A vintner who plants the vineyard in such a way that long-term sustainable management is difficult.

- Grape production: A vintner that does not operate in accordance with ecological/sustainable principles to produce high quality grapes.

- Wine production: A winery which does not operate so as to use resources efficiently and avoid errors, for producing and packaging quality wine on a high level.

- Social: A winery which does not fulfill the high legal standards for workers' rights and safety, and which does not take its social responsibility seriously.

- Economy: A winery that cannot exist economically in the long run.

\section{References}

[1] Bundesministerium für Land- und Forstwirtschaft, Umwelt und Wasserwirtschaft. http://www . bml fuw.gv. at/land/bio-lw/Biowein. html (2014.10.20) (2014)

[2] G.H. Brundtland (1987) Report of the World Commission on Environment and Development: Our Common Future. http://www. un-documents.net/our-common-future.pdf (04.28.2014), 41

[3] COM. Green paper: Promoting a European framework for Corporate Social responsibility. European Commission 366:3, 6 (2001)

[4] COM. Communication from the Commission on the European Competitiveness Report. European Commission 774:9 (2008)

[5] COM. A renewed EU strategy 2011-14 for Corporate Social Responsibility. European Commission 681:3 (2011)

[6] CSWA. The Code of Sustainable Winegrowing Workbook. Second edition (2006), p. viii

[7] CSWA. The Code of Sustainable Winegrowing Workbook. Second edition (2006), pp. 4-15

[8] Demeter. http://www. demeter. net/what is-demeter/biodynamic-preparations (04.28.2014) (2014)

[9] Grüner Bericht. Bundesministerium für Land- und Forstwirtschaft, Umwelt und Wasserwirtschaft http : / / www.gruenerbericht . at/cm3/ download/finish/82-gruener-bericht-oesterreich/649-gruener-bericht -2013/0.html (10.20.2014) (2013), p. 192

[10] Lodi. www. lodiwine.com/certified-green/ lodi-rules-for-sustainable-winegrowing (05.17.2011) (2011) p. 33

[11] S. Neubauer, Zertifizierungssysteme für eine nachhaltige Produktionsweise im Weinbau (Universität für Bodenkultur, 2011)

[12] OIV. Guidelines for sustainable vitiviniculture: production, processing and packaging of products. CST 1:2 (2008)

[13] G. Pesau, Ein Qualitätsweinbaubetrieb auf dem Prüfstand zum Thema Nachhaltigkeit (Universität für Bodenkultur, 2011)

[14] G. Soja, R. Rodriguez-Pascual, F. Zehetner, M. Gerzabek, L. Kühnen, G. Rampazzo-Todorovic, O. Duboc, B. Schildberger, K. Vogl, M. Mehofer, I. Omann, E. Burger, J. Haslinger, V. Dockner, S. Grünberger, M. Soja, R. Roch, K. Hackl, R. Hofmann (2010) Weinbau im Klimawandel: Anpassungsund Mitigationsmöglichkeiten am Beispiel der Modellregion Traisental. https: / / www . dafne. at/prod/dafne_plus_common/attachment_download/32dded 8 a4dc658099a25 a 3b0 $\overline{5} 88 \mathrm{~b} 657 \mathrm{e} / \mathrm{WEINKLIM}-$ Endbericht gesamt_2010-04-07a.pdf 